\title{
Anterior crossbite treatment in the transitional period of mixed dentition: a case
}

\section{report}

\author{
Tratamento da mordida cruzada anterior no período transitório da dentição mista: relato de caso \\ Tratamiento de la mordida cruzada anterior en el período de transición de la dentición mixta:
}

informe de un caso

Received: 09/29/2021 | Reviewed: 10/04/2021 | Accept: 10/06/2021| Published: 10/10/2021

\author{
Marcos Rogério de Mendonça \\ ORCID: https://orcid.org/0000-0001-8081-9144 \\ Universidade Estadual de Paulista, Brazil \\ E-mail: rogerio.mendonca@unesp.br \\ Mayra Fernanda Ferreira \\ ORCID: https://orcid.org/0000-0003-0442-3126 \\ Universidade Estadual de Paulista, Brazil \\ E-mail: mayra.fernanda@unesp.br \\ Priscila Maria Marchesini \\ ORCID: https://orcid.org/0000-0003-1670-2683 \\ Universidade Estadual de Paulista, Brazil \\ E-mail: marchesinipm@gmail.com \\ Tamires Passadori Martins \\ ORCID: https://orcid.org/0000-0003-4153-1548 \\ Universidade Estadual de Paulista, Brazil \\ -mail: tamires.passadori@unesp.br \\ Alberto Carlos Botazzo Delbem \\ ORCID: https://orcid.org/0000-0002-8159-4853 \\ Universidade Estadual de Paulista, Brazil \\ E-mail: alberto.delbem@unesp.br \\ Osmar Aparecido Cuoghi \\ ORCID: https://orcid.org/0000-0001-7085-9249 \\ Universidade Estadual de Paulista, Brazil \\ E-mail: osmar.cuogui@unesp.br
}

\begin{abstract}
Anterior crossbite refers to the abnormal vestibulolingual relationship in the sagittal dimension between one or more anterior superior and inferior anterior teeth. It can be classified as dental, functional or skeletal. Each has its own diagnostic criteria and specific treatment, and it is up to the dentist to know how to distinguish between these different natures of malocclusion. In this sense, the aim of this study is to show a case report about an ACM. Patient HCA, female, 7 years old, attending the Preventive Orthodontics Clinic of the Faculty of Dentistry of Araçatuba - UNESP, having as main complaint "untidy front tooth". The patient has no history of systemic diseases or medication use. The patient was in the first transitional period of mixed dentition with her right maxillary central incisor in crossbite relationship with its antagonists mandibular central incisor. On both sides, the patient had the first permanent molars in Class I relationship, the deciduous second molars with mesial step and the deciduous canines in a Class I. Initially, an acrylic appliance with an expander was installed. Due to lack of cooperation, the treatment plan was changed and the patient received a fixed appliance with a $2 \times 2$ configuration, with brackets on maxillary central incisors and edgewise tubes on maxillary deciduous molars. In the lower arch, a bite lift was performed on the occlusal surface of mandibular deciduous molars to unblock the occlusion and facilitate the movement of right maxillary central incisor. The total treatment time was 60 days.
\end{abstract}

Keywords: Corrective orthodontics; Malocclusion; Angle class I.

\section{Resumo}

A Mordida Cruzada Anterior refere-se à relação vestíbulo-lingual anormal na dimensão sagital entre um ou mais dentes anteriores superiores e inferiores. Pode ser classificado como dentário, funcional ou esquelético. Cada um tem seus próprios critérios de diagnósticos e tratamento específico, cabendo ao Cirurgião-Dentista saber distinguir entre essas diferentes naturezas de maloclusão. O objetivo deste estudo é apresentar um relato de caso sobre uma MCA. Paciente do sexo feminino, 7 anos de idade, foi atentida na clínica de Ortodontia Preventiva da Faculdade de Odontologia de 
Araçatuba - UNESP, tendo como principal queixa "dente torto". A paciente não tinha histórico de doenças sistêmicas ou uso de medicamentos. A paciente encontrava-se no primeiro período transitório da dentição mista, com o incisivo central superior cruzado com seu antagonista. Em ambos os lados, a paciente tinha os primeiros molares permanentes em uma relação de Classe I, os segundos molares decíduos com degrau mesial e os caninos decíduos em Classe I. Inicialmente, um aparelho removível com um parafuso expansor foi instalado. Por falta de colaboração, o plano de tratamento foi alterado e a paciente recebeu um aparelho fixo com configuração $2 \times 2$, com braquetes nos incisivos centrais superiores e tubos edgewise nos molares decíduos superiores. No arco inferior, um levante de mordida foi feito na superfície oclusal dos molares decíduos inferiores para desbloquear a oclusão e facilitar a movimentação do incisivo central superior direito. O tempo total de tratamento foi de 60 dias.

Palavras-chave: Ortodontia corretiva; Má oclusão; Má oclusão classe I de Angle.

\section{Resumen}

La mordida cruzada anterior se refiere a la relación bucolingual anormal en la dimensión sagital entre uno o más dientes anteriores superiores e inferiores. Puede clasificarse como dental, funcional o esquelética. Cada una de ellas tiene sus propios criterios de diagnóstico y tratamiento específico, y corresponde al cirujano dental distinguir entre estos diferentes tipos de maloclusión. El propósito de este estudio es presentar un informe de caso sobre una MCA. Una paciente de 7 años fue atendida en la Clínica de Ortodoncia Preventiva de la Facultad de Odontología de Araçatuba UNESP, quejándose de "dientes torcidos". Paciente sin antecedentes de enfermedades sistémicas ni uso de medicamentos. La paciente se encontraba en el primer periodo de transición de la dentición mixta y el incisivo central superior derecho tenía una relación de mordida cruzada anterior con su antagonista. En ambos lados, la paciente tenía los primeros molares permanentes en una relación de Clase I, los segundos molares deciduos con un paso mesial a la mandíbula y los caninos deciduos en Clase I. Inicialmente, se instaló un aparato acrílico con un tornillo expansor. Debido a la falta de cumplimiento, se cambió el plan de tratamiento y la paciente recibió un aparato fijo con una configuración de 2x2, con brackets en los incisivos centrales maxilares y tubos de canto en los molares deciduos maxilares. En la arcada inferior, se realizó una elevación de la mordida en la superficie oclusal de los molares deciduos inferiores para desbloquear la oclusión y facilitar el movimiento del incisivo central superior derecho. El tiempo total de tratamiento fue de 60 días.

Palabras clave: Ortodoncia correctiva; Maloclusión; Maloclusión clase I de Angle.

\section{Introduction}

Anterior crossbite (AC) is the inversion of the ideal horizontal relationship between the maxillary and mandibular incisors when both arches are in centric occlusion (Salzman, 2013).

It is a important problem in childrens, so the American Association of Orthodontists (AAO,2017) recommend your treat ment as early as possible, and the general dentist have a essential role in early diagnosis. Janson et al. reveled its prevalence is equivalent to $4.55 \%$ of children in the mixed dentition (Janson et al., 2013), although exists conflited numbers, since it depends on the age of the analyzed children, sample quantity and country of origin. Shalish et al. analyzed a total of 432 school students in Jerusalem in the mixed dentition, 7-11 years of age, and found out that $8.5 \%$ of children caries-free had anterior crossbite malocclusion; whilst the anterior crossbite was present in $15.4 \%$ caries-affected children (Shalish et al., 2013). Reddy el at. showed that $4.49 \%$ of a total of 2135 Indian children, aged between $6-10$ years has ACM as well (Reddy el at., 2013).. A Germany study with 494 children, around 9 years age, showed that $3.4 \%$ males and $5.1 \%$ females had a crossbite (anterior and posterior), with the anterior crossbite particularly affecting lateral incisors (Lux et al., 2009). Anterior crossbite is a condition that establishes and presents in the mixed dentition (Kasparaviciene et al., 2014; Silvestrini-Biavati et al., 2016), and depending on the etiology and clinical presentation, it can be classified as your nature as dental, functional or skeletal (Millet et al., 2005). Each one of its categories has its own diagnostic and proper treatment, and it is up to the dentist know and treat these characteristic malocclusion (Borrie et al., 2011).

Dental anterior crossbite often involves a single tooth and these patients have normal anteroposterior skeletal relationship, to the point that skeletal anterior crossbite usually has genetic involvement and changes in the patient's facial pattern (Sockalingam et al., 2018; Sexton et al., 1983). An abnormal bite between the opposing teeth can also cause gingival recession and loss of alveolar bone support to the lower incisor (Sockalingam et al., 2018; Ustun et al., 2008), as such potential adverse growth influences on the mandible and the anterior portion on the maxilla as well (Sexton et al., 1983; Valentine \& Howitt, 
1970). It is important to point out that mixed dentition period is considered the best age to correct malocclusions, and intercepting at the right age can improve and better guide maxillomandibular growth (Iqbal et al., 2019; Tung \& Kiyak, 1998; Singh et al., 2015; AAO, 2017).

When properly diagnosed, the treatment for anterior crossbite is not invasive, and is usually simple and may or may not be acted upon by the patient's cooperation; depending on the type of appliance chosen for the treatment (Borrie et al., 2011; Mckeown \& Sandlerd, 2001; Yaseen \& Acharya, 2012; Jirgensone et al., 2008; Dowsing \& Sandler, 2004). In the present clinical case, a patient diagnosed with dental anterior crossbite will be discussed for treatment.

\section{Methodology}

The clinical case report was documented at the Faculty of Dentistry of Araçatuba FOA - UNESP, with proper authorization from responsible, who were instructed about treatment options, risks and prognosis by the Consent Term. This study is a case report, qualitative and descriptive (Pereira et al.,2018).

\section{Results and Discussion}

Female patient, 7 years old, attending the Preventive Orthodontics Clinic of the Faculty of Dentistry of Araçatuba UNESP, having as main complaint "untidy front tooth". The patient's general health status was adequate, with no history of systemic diseases or medication use.

In the facial analysis at the front view, the patient had a balanced face, mesocephalic pattern, with inadequate lip seal and no asymmetries. At the profile view, the patient had a gently convex facial profile (Figure 1).

Figure 1: Image of the patient in front view, profile and smilling, respectively.
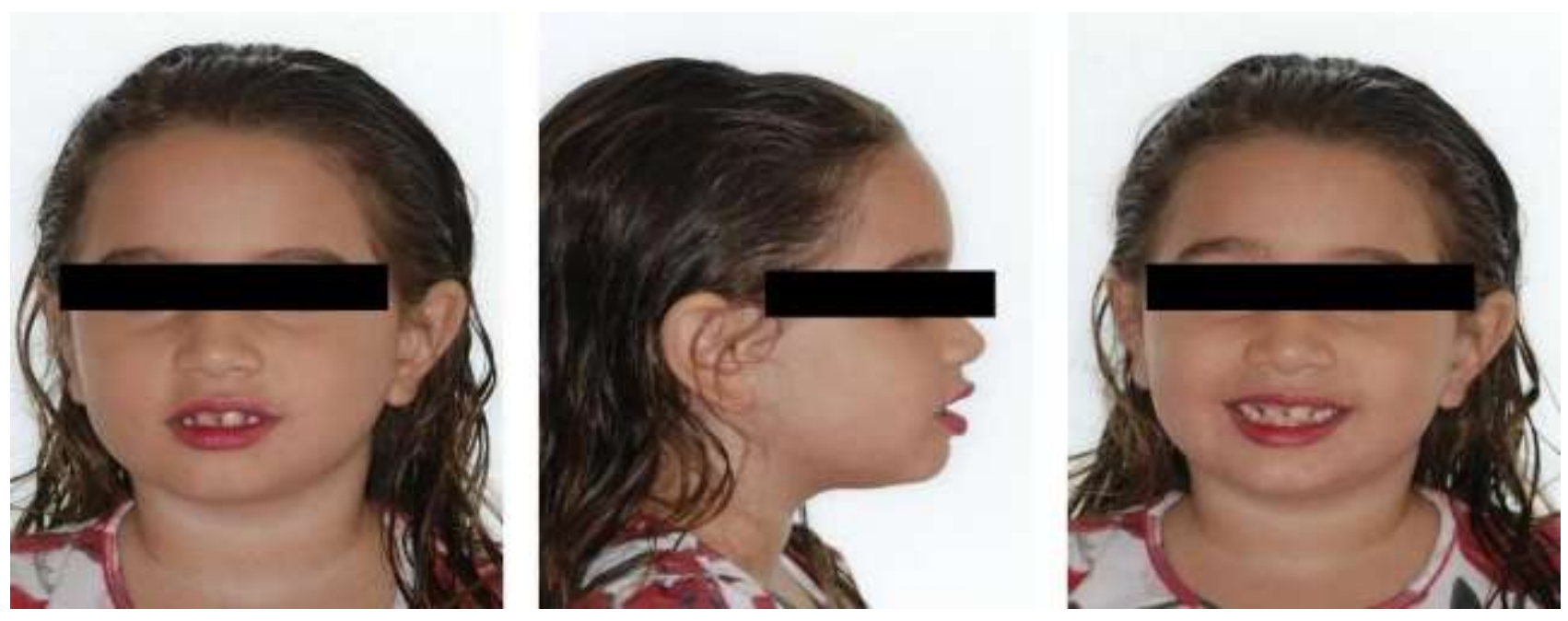

Source: Authors.

Intrabuccal analysis the patient was in the first transitional period of mixed dentition according to Van der Linden (Van der Linden, 2013). In the frontal view, the patient has a adequate overbite, her right maxillary central incisor was in crossbite relationship with its antagonists mandibular central incisor, and the transversal relationship between maxillary and mandibular teeth is adequate. On both sides, the patient had the first permanent molars in Class I relationship, the deciduous second molars with mesial step to the mandible and the deciduous canines in a Class I (Figure 2). 
Figure 2: Right side, front side and left side of the patient's dentition, respectively.
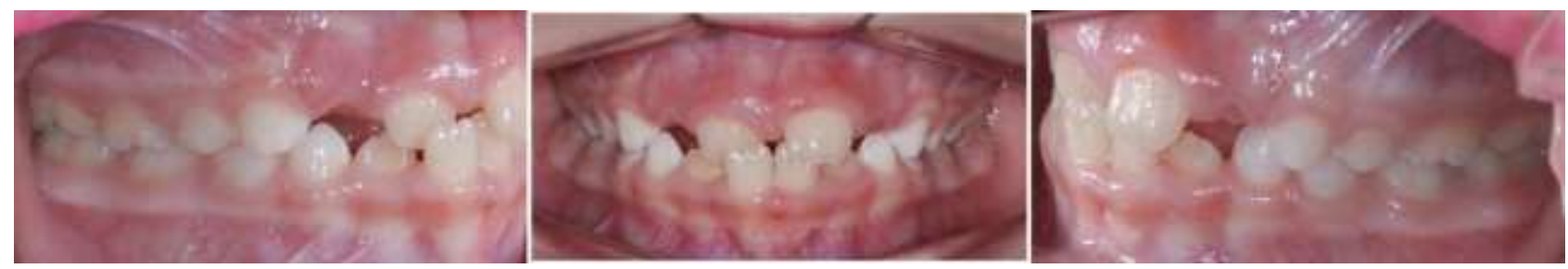

Source: Authors.

In the upper occlusal view, the patient presented spacing between the maxillary incisors and a large square-shaped maxilla, with no signs of atresia, while the mandibular arch presented a normal form with crowding in the four permanent incisors (Figure 3).

Figure 3: Upper arch and lower arch, respectively.

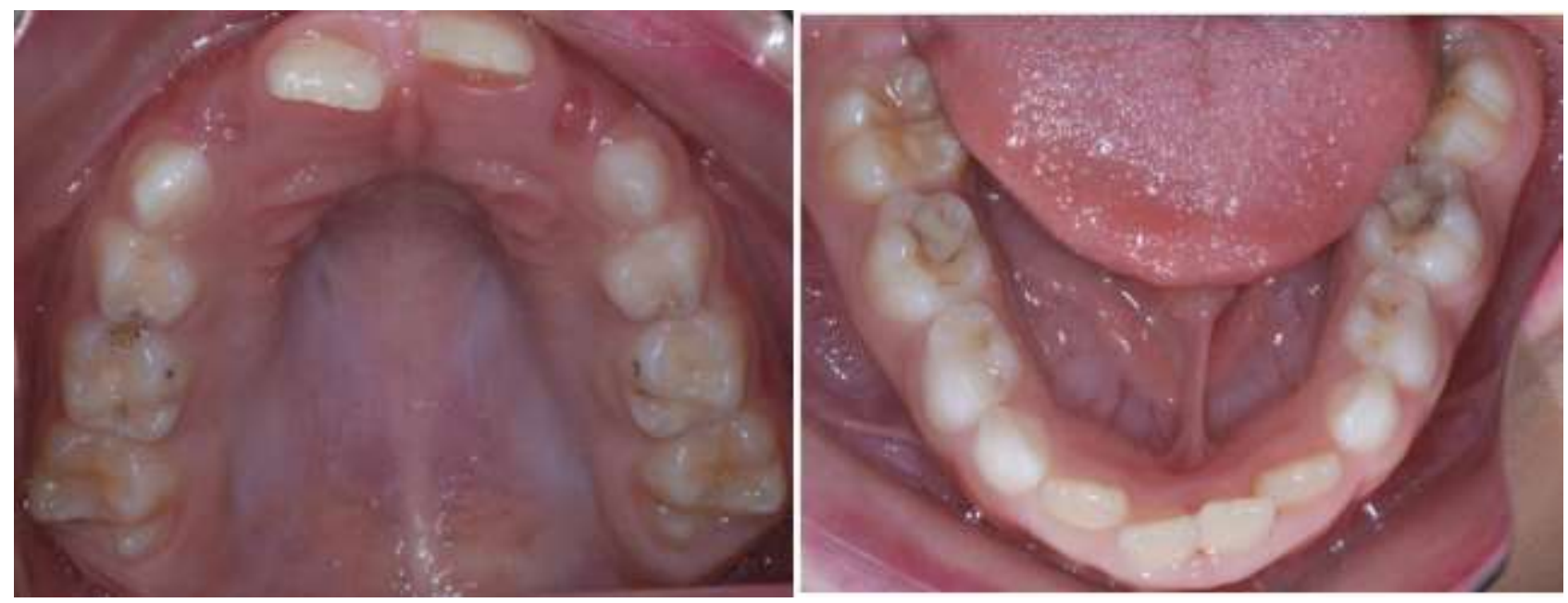

Source: Authors.

With complementary exams, panoramic radiographs (orthopantomografh) and periapical radiographs of mandibular and maxilary central incisors were performed (Figures 4 and 5). The panoramic radiograph showed Figures of normality for the dentition phase, without anomalies in position and number. Her maxillary canines was in vertical position as well. For this case, teleradiography in lateral form was not required due to the dental nature of the malocclusion, which prevents unnecessary radiation. With all this, the diagnosis for the case was Class I with dental anterior crossbite. 
Research, Society and Development, v. 10, n. 13, e186101321234, 2021

(CC BY 4.0) | ISSN 2525-3409 | DOI: http://dx.doi.org/10.33448/rsd-v10i13.21234

Figure 4: Initial panoramic radiography.

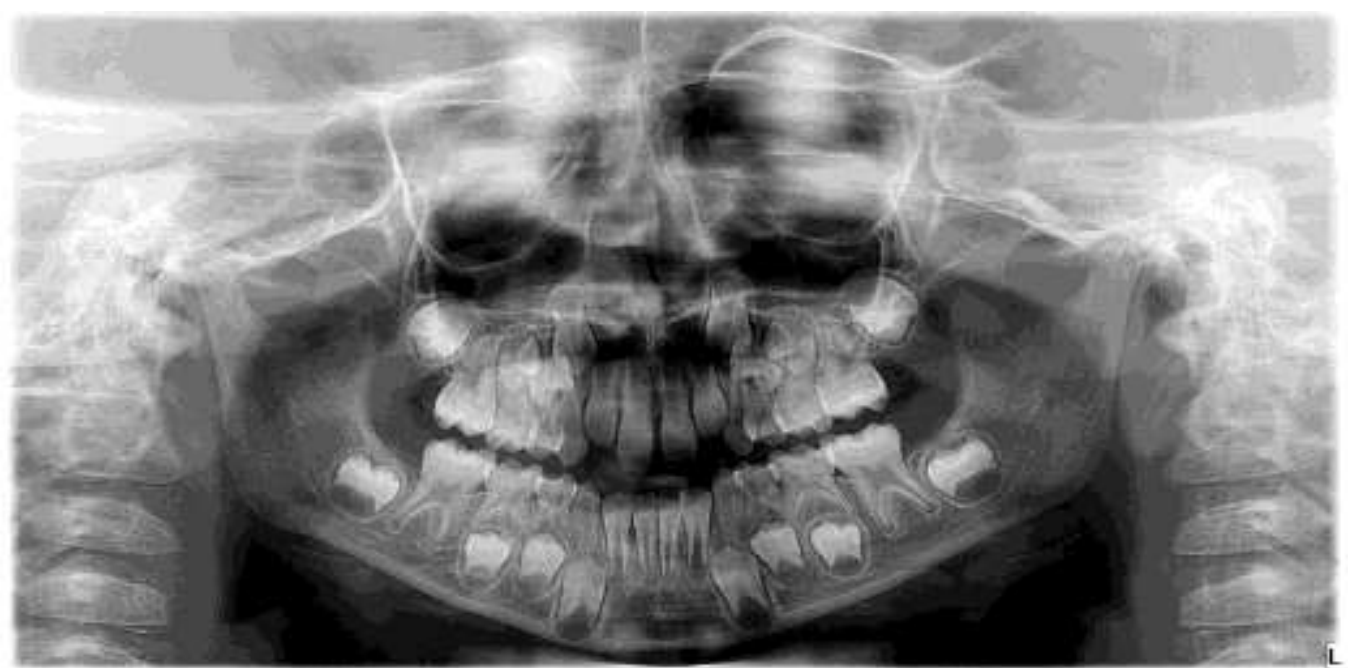

Source: Authors.

Figure 5: Periapical radiograph in the region of the upper and lower incisors.
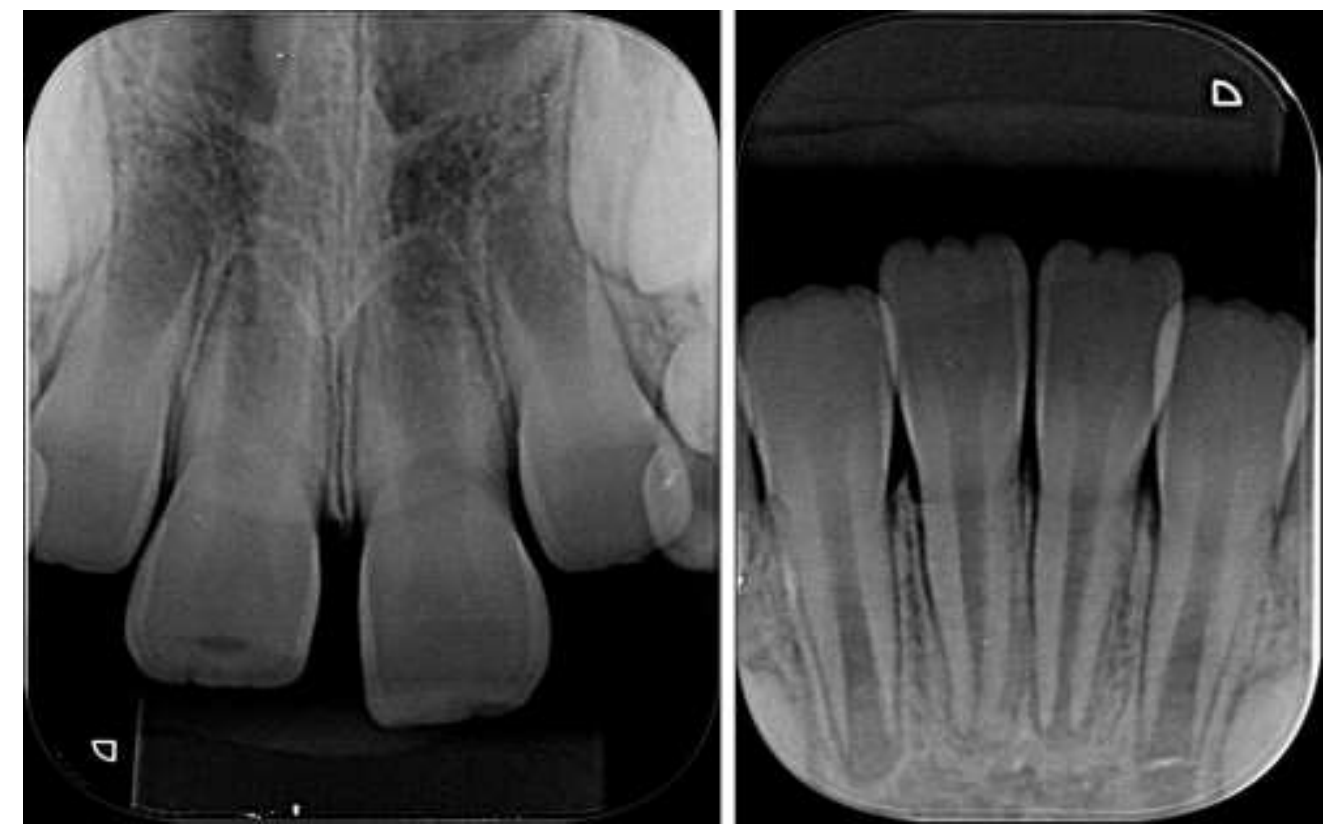

Source: Authors.

At first, an acrylic appliance with an expander screw was installed. The screw had activation in the anteroposterior direction, and the patient parent were instructed to activate the screw $1 / 4$ turn per week, and use it for the maximum number of hours during the day (Figure 6). 
Figure 6: Initially, an acrylic appliance was installed on the patient.
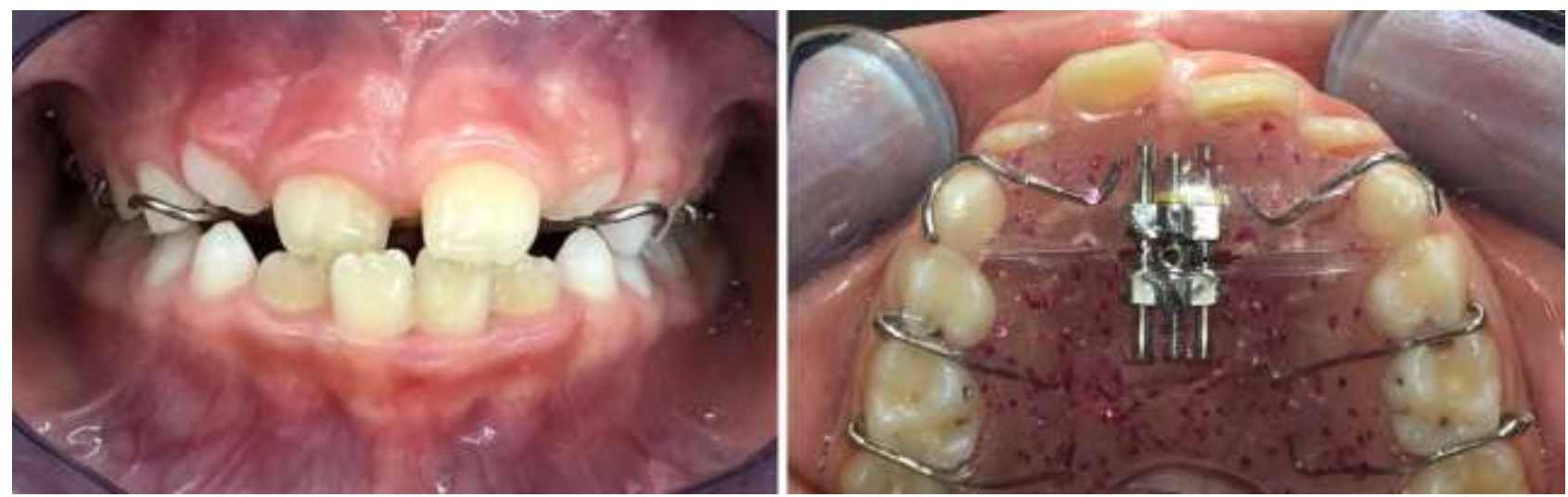

Source: Authors.

Due of lack of cooperation, the appliance not work well, and in this way, the treatment plan was changed and the patient received a fixed appliance with a $2 \times 2$ configuration, with bonded brackets on maxillary central incisors and tubes on maxillary second deciduous molars. The prescription of the fixed appliance was not important because the brakets were positioned of passive form. The system was activated using nickel-titanium wires 0.012 ", and used for 30 days followed by a nickel-titanium wires 0.014" (Figure 7). In the lower arch, a built up was performed on the occlusal surface of second mandibular deciduous molars to unblock the occlusion and facilitate the movement of right maxillary central incisor. The total treatment time was 60 days, and the result was satisfactory (Figure 8).

Figure 7: Right side, front side and left side of $2 \times 2$ configuration, respectively.
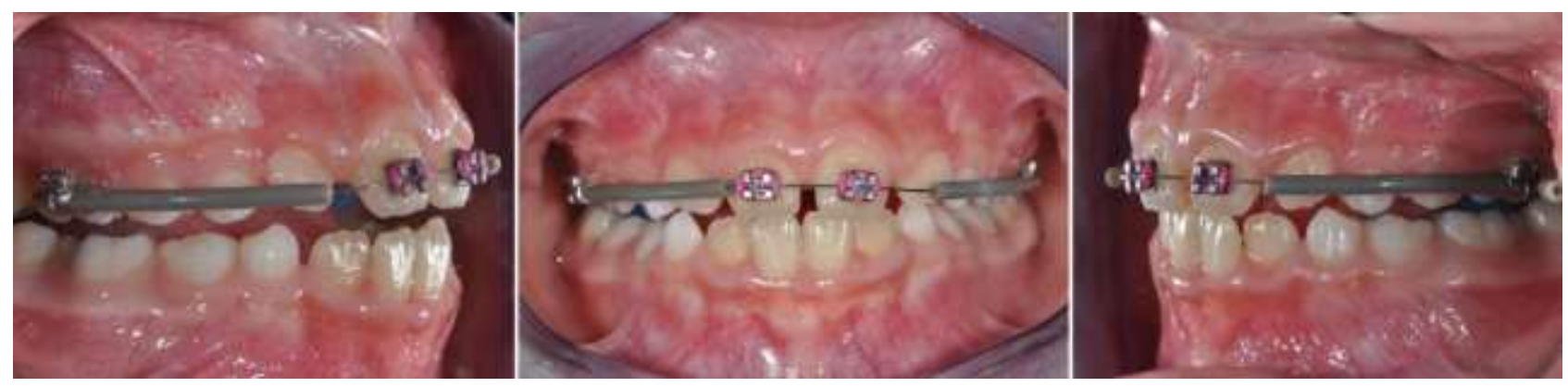

Source: Authors.

Figure 8: Right side, front side and left side of the final treatment of the patient.
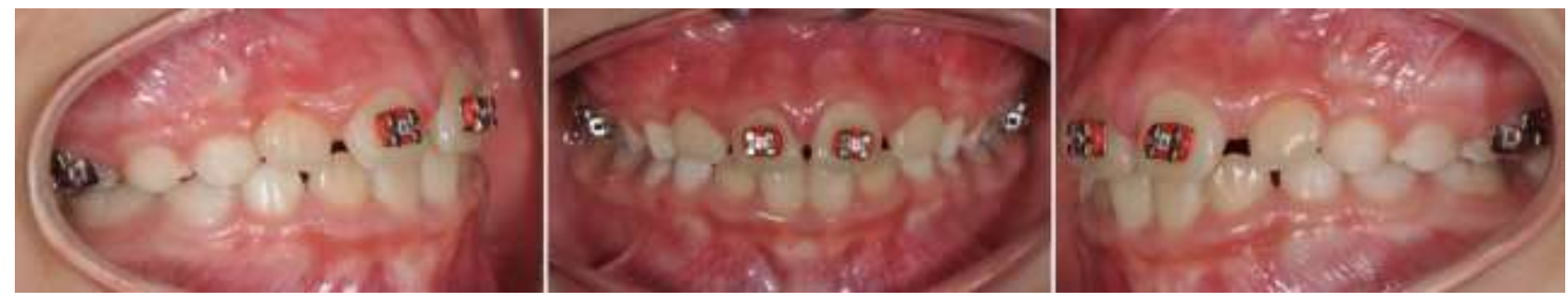

Source: Authors.

\section{Conclusion}

The results were obtained as planned: anterior teeth in normal occlusion. The patient and the parents demonstrated to be satisfied with the results. When certainly diagnosed, anterior crossbite can have a quick and simple approach with an effective 
treatment, being beneficial to provide aesthetic and social well-being of the child, in addition to a more appropriate and correct occlusion.

\section{References}

American Association of Orthodontists (2017). Problems to Watch for in Seven Year Olds. https://www.aaoinfo.org/1/problems-to-watch-for-7.

Borrie, F. \& Bearn, D. (2011). Early correction of anterior crossbites: a systematic review. J Orthod. 38(3):175-84.

Dowsing P., Sandler J. (2004) How to effectively use a $2 \times 4$ appliance. 31(3):248-258.

Janson, G., Garib, D. G., Pinzan, A., Henriques, J. F. C. \& Freitas, M. R. (2013). Introdução à Ortodontia. Artes Médicas: Odontologia Essencial, São Paulo

Iqbal N., Farooq S. (2019) Intercept Rightly To Allign Properly: Management of Reverse Articulation By 2 By 4 Appliances. International Journal of Dental Science and Innovative Research (IJDSIR). Volume - 2, Issue - 6, November - December, Page No. : 171 - 175.

Jirgensone I., Liepa A., Abeltins A. (2008). Anterior crossbite correction in primary and mixed dentition with removable inclined plane (Bruckl appliance) .10(4):140-144.

Kasparaviciene K., Sidlauskas A., Zasciurinskiene E., Vasiliauskas A., Juodzbalys G., Sidlauskas M., Marmaite U. (2014). The prevalence of malocclusion and oral habits among 5-7-year-old children. Medical Science Monitor: International Medical Journal of Experimental and Clinical Research. 20:2036-2042.

Lux CJ., Dücker B., Pritsch M., Komposch G., Niekusch U. (2009). Occlusal status and prevalence of occlusal malocclusion traits among 9-year-old schoolchildren. Eur J Orthod. 31: 294-99.

Millet D., Welbury R. (2005). Clinical Problem Solving in Orthodontics and Paediatric Dentistry, Elsevier Churchill Livingstone, Edinburgh.

Mckeown H. F., Sandlerd J. (2001). The two by four appliance: a versatile appliance. 28(10):496-500.

Pereira A. S. et al. (2018). Metodologia da pesquisa científica.

Reddy ER., Manjula M., Sreelakshmi N., Rani ST., Aduri R., Patil BD. (2013). Prevalence of Malocclusion among 6 to 10 Year old Nalgonda School Children. J Int Oral Health. 5(6):49-54.

Salzman, J. A. (1968). Handicapping malocclusion assessment to establish treatment priority. Am J Orthod. 54: 749-69.

Sexton T., Croll TP. (1983). Anterior crossbite correction in the primary dentition using reversed stainless steel crowns. ASDC J Dent Child. 50: 117-20.

Silvestrini-Biavati A., Salamone S., Silvestrini-Biavati F., Agostino P., Ugolini A. (2016). Anterior open-bite and sucking habits in Italian preschool children. Eur J Paediatric Dent. 1(1):43-6.

Singh S. P., Kumar V., Narboo P. (2015). Prevalence of malocclusion among children and adolescents in various school of Leh Region. 1(2):1-6.

Sockalingam SNMP., Khan KAM., Kuppusamy E. (2018). Interceptive Correction of Anterior Crossbite Using Short-Span Wire-Fixed Orthodontic Appliance: A Report of Three Cases. Case Rep Dent. Apr 29;2018:4323945.

Shalish M., Gal A., Brin I., Zini A., Ben-Bassat Y. (2013). Prevalence of dental features that indicate a need for early orthodontic treatment. Eur J Orthod. Aug;35(4):454-9.

Tung, A. W., Kiyak. H. A. (1998). Pshychological influences on the timing of orthodontic treatment”. American Journal of Orthodontics and Dentofacial Orthopedics. 113(1998), 29-39.

Ustun K., Sari Z., Orucoglu H., Duran I., Hakki S. S. (2008). Severe gingival recession caused by traumatic occlusion and mucogingival stress: a case report. $2: 127-133$.

Van der Linden, FPGM (2013). Development of the human dentition: An atlas. Quintessence Publishing Co, Inc, Chicago.

Valentine F., Howitt JW. (1970). Implications of early anterior crossbite correction. ASDC J Dent Child. 37, 420-27.

Yaseen S. M., Acharya R. (2012). Hexa helix: modified quad helix appliance to correct anterior and posterior crossbites in mixed dentition. 2012:5. 